\title{
Effect of vegetation on the performance of horizontal subsurface flow constructed wetlands with lightweight expanded clay aggregates
}

\author{
M. C. Mesquita • A. Albuquerque • L. Amaral • \\ R. Nogueira
}

Received: 18 December 2011/Revised: 22 May 2012/ Accepted: 9 October 2012/Published online: 24 November 2012

(C) CEERS, IAU 2012

\begin{abstract}
This research evaluates the effect of both organic and ammonia loading rates and the presence of plants on the removal of chemical oxygen demand and ammonia nitrogen in horizontal subsurface flow constructed wetlands, 2 years after the start-up. Two sets of experiments were carried out in two mesocosms at different organic and ammonia loading rates (the loads were doubled); one without plants (control bed), the other colonized with Phragmites australis. Regardless of the organic loading rate, the organic mass removal rate was improved in the presence of plants $(93.4 \%$ higher for the lower loading rate, and $56 \%$ higher for the higher loading rate). Similar results were observed for the ammonia mass removal rate $(117 \%$ higher for the lower loading rate, and
\end{abstract}

M. C. Mesquita

High School of Agriculture, Polytechnic Institute of Castelo

Branco, Quinta da Senhora de Mércules, Apartado 119, 6001-909 Castelo Branco, Portugal

e-mail: cmesquita@ipcb.pt

A. Albuquerque $(\square)$

Department of Civil Engineering and Architecture,

University of Beira Interior, Bloco II das Engenharias,

Calçada do Lameiro, 6201-001 Covilha, Portugal

e-mail: ajca@ubi.pt

L. Amaral

Department of Sciences and Environmental Engineering, Faculty of Sciences and Technology, New University of Lisbon, 2829-516 Caparica, Portugal

e-mail:1mma@fct.unl.pt

R. Nogueira

Institute for Sanitary Engineering and Waste Management,

University of Hannover, Welfengarten 1,

D-30167 Hannover, Germany

e-mail: nogueira@isah.uni-hannover.de
$61.3 \%$ higher for the higher loading rate). A significant linear relationship was observed between the organic loading rate and the respective removal rates in both beds for loads between 10 and $13 \mathrm{~g} \mathrm{~m}^{-2}$ day $^{-1}$. The presence of plants markedly increase removal of organic matter and ammonia, as a result of the role of roots and rhizomes in providing oxygen for aerobic removal pathways, a higher surface area for the adhesion and development of biofilm and nitrogen uptake by roots.

Keywords Constructed wetlands - Lightweight expanded clay aggregates $\cdot$ Loading rate $\cdot$ Nitrogen removal $\cdot$ Organic matter removal $\cdot$ Phragmites australis $\cdot$ Subsurface flow

\section{Introduction}

Constructed wetland (CW) systems with reeds and horizontal subsurface flow (HSFW) have been used for the treatment of domestic wastewater, industrial effluents, landfill leachate, polluted river water and stormwater runoff, among others (Juang and Chen 2007; Vymazal and Kropfelova 2008; Vymazal 2009; Albuquerque et al. 2009a; Randerson et al. 2010; Bialowiec et al. 2012a). The main advantages of these systems include low costs of construction, maintenance and operation in comparison with activated sludge, anaerobic digestion or percolating filters for the same population size and similar flow rates and pollutant loads (Vymazal and Kropfelova 2008; Kadlec and Wallace 2008). Therefore, nowadays there has been an increase in their use for domestic and wastewater treatment, as well as for advanced and polishing treatment if water reuse is an option (Masi and Martinuzzib 2007; Marecos do Monte and Albuquerque 2010; Pedrero et al. 2011a, b; Amado et al. 2012; Bialowiec et al. 2012a, b). 
Although plants are one of the most important components of the wetland ecosystem, pollutant removal is also accomplished through an integrated combination of biological, physical and chemical processes. The substrate and the coupled microbial communities can remove a broad range of undesired constituents (organics, nutrients, heavy metals and solids) commonly found in wastewaters (Vymazal and Kropfelova 2008; Lu and Huang 2010), through mechanisms such as filtration, sedimentation, biochemical pathways (e.g. aerobic respiration, nitrification, denitrification, anaerobic respiration and other nonconventional pathways), adsorption, precipitation, volatilisation and plant uptake (Paredes et al. 2007; Vymazal 2007, 2009; Kadlec and Wallace 2008).

HSFW beds are the most widely applied CW systems due to the simple technology used, reliable operating conditions and good potential to remove moderate loads of organics, nitrogen, phosphorous and solids. Removal efficiencies above $90 \%$ are normally achieved for suspended solids and organic matter [such as chemical oxygen demand (COD)] and up to $50 \%$ may be expected for nitrogen (Vymazal 2007, 2009; Kadlec and Wallace 2008). Light-expanded clay aggregates (LECA) can be used to improve the treatment capacity since they present both higher porosity and specific surface area, which allow a better biofilm adhesion and require smaller bed areas than the conventional gravel substrate (Albuquerque et al. 2009b; Bialowiec et al. 2011, 2012b).

The removal rates and performance of HSFW may vary over time and space and are dependent on multiple factors such as influent wastewater characteristics, hydraulic loading rate (HLR), organic loading rate (OLR), nitrogen loading rate (NLR), hydraulic residence time (HRT), bed maturity, media size, bed depth, plant species, among others (Stottmeister et al. 2003; Kadlec and Wallace 2008; Albuquerque et al. 2009a; Vymazal 2009; Cheng et al. 2011; Bialowiec et al. 2012a, b). As with many other natural wastewater treatment systems, pollutant removal processes in a HSFW bed are affected by the variations of OLR and NLR that may produce a quick change in the removal rates of $\mathrm{COD}\left(r_{\mathrm{COD}}\right)$ and ammonia nitrogen $\left(r_{\mathrm{NH}_{4} \mathrm{~N}}\right)$ and this effect is not well studied for LECA-based beds. Such changes are also dependent on the oxygen transferred to the subsurface environment through roots or direct nitrogen assimilation by plants (Vymazal and Kropfelova 2008; Bialowiec et al. 2012a). Vegetation presents a thermoregulatory effect (Kadlec and Wallace 2008; Brisson and Chazarenc 2009; Bialowiec et al. 2012b) and this mechanism positively affects most biological pathways. On the other hand, the growth and development of roots and rhizomes provide surface for microbial growth, which benefits most of the microbiological removal pathways.
OLR, NLR, HLR and HRT are important variables for the design and operation of HSFW. The removal efficiencies of organics, nitrogen and phosphorous depend on the oxidation-reduction conditions, which are influenced by several factors including the applied loads (Kadlec and Wallace 2008; Albuquerque et al. 2009b; Lu and Huang 2010). If the pollutant loading rate exceeds the oxygen transfer rate, the aerobic decomposition of organic matter and the nitrification process may be inhibited. Therefore, pollutant removal may be optimized by balancing the pollutant loading rate and the oxygen transfer. In general, low organic loads promote more oxidised conditions and therefore a better performance than high loads. The recommended loading rates range widely (Kadlec and Wallace 2008; Vymazal and Kropfelova 2008), indicating not only the inherent dynamics and variability in natural treatment systems but also the need for a better understanding of removal processes and improved design guidelines. Paredes et al. (2007) observed that NLR correlated strongly with effluent loading for ammonia nitrogen $\left(\mathrm{NH}_{4}-\mathrm{N}\right)$; however, they also observed that NLR did not correlate with $r_{\mathrm{NH}_{4} \mathrm{~N}}$. Therefore, the influence of NLR on final effluent nitrogen concentrations and removal rates is yet unclear and not well known for LECA-based beds.

The inconsistency of the results found in studies with HSFW for the removal of COD and $\mathrm{NH}_{4}-\mathrm{N}$, as well as the effect of vegetation for different loading conditions (Jing et al. 2002; Akratos and Tsihrintzis 2007; Albuquerque et al. 2009a; Brisson and Chazarenc 2009; Pedrero et al. 2011a; Amado et al. 2012) and the absence of studies for LECA-based HSFW suggested the development of this research work. Therefore, the aim of this work was to evaluate the impact of reeds (Phragmites australis), OLR and NLR on the removal of COD and $\mathrm{NH}_{4}-\mathrm{N}$ in LECAbased beds under the same HLR, and was developed from March 2009 to October 2010 at the Department of Civil Engineering and Architecture of the University of Beira Interior (Covilhã, Portugal).

\section{Materials and methods}

\section{Experimental setup}

Two HSFW with approximately $2 \times 0.8 \times 0.7 \mathrm{~m}$ (length $\times$ width $\times$ height) were run in parallel, one unplanted (control bed), the other planted with reeds (Phragmites australis). The effective surface areas were approximately $0.65 \mathrm{~m}^{2}$ and both beds were filled with LECA (Filtralite NR aggregates with an effective diameter ranging from 4 to $8 \mathrm{~mm}$, specific surface area of $1,250 \mathrm{~m}^{2} \mathrm{~m}^{-3}$ and void ratio of 0.45 ). The planted bed was colonised two years before the experiments (i.e. the plants were well developed during 
the experiments). The water table was fixed at $0.2 \mathrm{~m}$. Three sampling points (PI2, PI5 and PI8) were used inside each bed to collect water samples for analytical measurements as shown in Fig. 1, with the following lengths: PI2 $(0.33 \mathrm{~m}$ away from the inlet), PI5 (1 m away from the inlet) and PI8 (1.9 $\mathrm{m}$ away from the inlet). The inlet device was composed by a perforated " $\mathrm{T}$ " tube connected to a peristaltic pump (Ismatec MCP-CA4, Switzerland), which pumped the feeding solution from a temperature-controlled storage tank (ISCO FTD 220, Italy) to the beds.

\section{Feeding solution}

Synthetic wastewater was used in the experiments, which included an organic carbon source (sodium acetate solution), a nitrogen source (ammonia chloride) and a mineral source as used in Albuquerque et al. (2009b). All the solutions were prepared as concentrated ones according to the following composition: buffer solution $[(8.50 \mathrm{~g}$ $\mathrm{KH}_{2} \mathrm{PO}_{4}+21.75 \mathrm{~g} \mathrm{~K}_{2} \mathrm{HPO}_{4}+33.40 \mathrm{~g} \mathrm{Na}_{2} \mathrm{HPO}_{4} \cdot 7 \mathrm{H}_{2} \mathrm{O}+$ $1.70 \mathrm{~g} \mathrm{NH} \mathrm{NCl}_{4} \mathrm{~L}^{-1}$, magnesium sulphate solution [(22.50 $\left.\left.\mathrm{g} \mathrm{MgSO}_{4} \cdot 7 \mathrm{H}_{2} \mathrm{O}\right) \mathrm{L}^{-1}\right)$, calcium chloride solution (36.43 $\left.\mathrm{g} \mathrm{CaCl}_{2} \cdot 2 \mathrm{H}_{2} \mathrm{O} \mathrm{L}^{-1}\right)$, iron chloride solution $(0.25 \mathrm{~g}$ $\mathrm{FeCl}_{3} \cdot 6 \mathrm{H}_{2} \mathrm{O} \mathrm{L}{ }^{-1}$ ), oligoelements solution $\left[0.04 \mathrm{~g} \mathrm{MnSO}_{4}\right.$. $4 \mathrm{H}_{2} \mathrm{O}+0.06 \mathrm{~g} \mathrm{H}_{3} \mathrm{BO}_{3}+0.04 \mathrm{~g} \mathrm{ZnSO}_{2} \cdot 7 \mathrm{H}_{2} \mathrm{O}+0.032 \mathrm{~g}$ $\left(\mathrm{NH}_{4}\right)_{6} \cdot \mathrm{Mo}_{7} \mathrm{O}_{24} \cdot 4 \mathrm{H}_{2} \mathrm{O}+0.0555 \mathrm{~g}$ EDTA $+0.0445 \mathrm{~g} \mathrm{FeCl}_{3}$. $\left.6 \mathrm{H}_{2} \mathrm{O}\right) \mathrm{L}^{-1}$ ], sodium acetate solution $\left(113.4 \mathrm{~g} \mathrm{C}_{2} \mathrm{H}_{3} \mathrm{O}_{2} \mathrm{Na}\right.$. $3 \mathrm{H}_{2} \mathrm{O} \mathrm{L}^{-1}$, which gave $50 \mathrm{~g} \mathrm{COD} \mathrm{L}^{-1}$ ) and ammonia chloride solution $\left(76.41 \mathrm{~g} \mathrm{NH}_{4} \mathrm{Cl} \mathrm{L}^{-1}\right.$, which gave $20 \mathrm{~g} \mathrm{~N} \mathrm{~L}^{-1}$ ). The desired concentrations of COD and $\mathrm{NH}_{4}-\mathrm{N}$ for the experiments were obtained by diluting the concentrated solutions of sodium acetate and ammonia chloride. The feeding solution was kept in the storage tank $(72 \mathrm{~L})$ at constant temperature $\left(4 \pm 0.2{ }^{\circ} \mathrm{C}\right)$ and was changed each 3 days.

\section{Operating conditions}

The mesocosms were continuously fed during 50 days (8 weeks) for a flow rate of $1 \mathrm{~L} \mathrm{~h}^{-1}$ (HLR of approximately $3.6 \mathrm{~cm} \mathrm{day}^{-1}$, which corresponded to an HRT of approximately 6 days divided by the effective bed volume). Two sets of experiments were carried out: Phase I at COD concentrations of $\sim 300 \mathrm{mg} \mathrm{L}^{-1}$ (OLR $\sim 10 \mathrm{~g}$ $\mathrm{COD} \mathrm{m}{ }^{-2}$ day $^{-1}$ ) and $\mathrm{NH}_{4}-\mathrm{N}$ concentrations of $\sim 30 \mathrm{mg} \mathrm{L}^{-1}$ (NLR $\sim 1 \mathrm{~g} \mathrm{NH}_{4}-\mathrm{N} \mathrm{m}^{-2}$ day $^{-1}$ ), followed by Phase II at COD concentrations of $\sim 500 \mathrm{mg} \mathrm{L}^{-1}$ (OLR $\sim 20 \mathrm{~g} \mathrm{COD} \mathrm{m}^{-2} \mathrm{day}^{-1}$ ) and $\mathrm{NH}_{4}-\mathrm{N}$ concentrations of $\sim 50 \mathrm{mg} \mathrm{L}^{-1}$ (NLR $\sim 2 \mathrm{~g} \mathrm{NH}_{4}-\mathrm{N} \mathrm{m}^{-2}$ day $^{-1}$ ). In any case, the $\mathrm{COD} / \mathrm{N}$ ratio was $\sim 10$ (corresponding to a $\mathrm{C} / \mathrm{N}$ ratio of $\sim 4$ ). Weekly water samples were collected from the influent and at the sampling points PI2, PI5 and PI8 (the samples from PI8 were considered as effluent samples, since it was located close to the discharge point as also admitted in Albuquerque et al. (2009b)) to analyse the temperature, $\mathrm{pH}$, dissolved oxygen (DO), $\mathrm{COD}, \mathrm{NH}_{4}-\mathrm{N}$, nitrite nitrogen $\left(\mathrm{NO}_{2}-\mathrm{N}\right)$ and nitrate nitrogen $\left(\mathrm{NO}_{3}-\mathrm{N}\right)$. The temperature in the room was $20 \pm 0.4{ }^{\circ} \mathrm{C}$.

Analytical methods

The measurements of temperature, $\mathrm{pH}$ and $\mathrm{DO}$ were carried out through probes Sentix 41 and CellOx 325 connected to a Multi 340i meter (WTW, Germany). The COD was evaluated by closed reflux digestion and using titrimetric method (APHA-AWWA-WEF 1999). Concentrations of $\mathrm{NH}_{4}-\mathrm{N}, \mathrm{NO}_{2}-\mathrm{N}$ and $\mathrm{NO}_{3}-\mathrm{N}$ were obtained using the cuvette-tests LCK 302 (47-130 mg NH $\mathrm{NH}_{4}-\mathrm{N} \mathrm{L}^{-1}$ ), LCK 303 (2-47 mg NH $\left.\mathrm{NH} \mathrm{L}^{-1}\right)$, LCK $342\left(0.6-6 \mathrm{mg} \mathrm{NO} 2^{-}\right.$ $\left.\mathrm{N} \mathrm{L}^{-1}\right)$, LCK $339\left(0.23-13.5 \mathrm{mg} \mathrm{NO}{ }_{3}-\mathrm{N} \mathrm{L}^{-1}\right)$ and LCK 340 (5-35 mg NO$-\mathrm{N} \mathrm{L}^{-1}$ ), following the standards DIN 38406-E 5-1 (ammonia), DIN 38405 D10 (nitrite) and DIN 38405-9 (nitrate), and the CADAS 50 spectrophotometer UV-Vis (HACH LANGE, Germany).

Statistical analysis was executed through one-way ANOVA (analysis of variance), considering a significance level of $P<0.05$. The mass removal rates (in $\mathrm{g} \mathrm{m}^{-2} \mathrm{day}^{-1}$ ) were calculated through the difference of concentrations in the influent and the effluent (point PI8) times the flow-rate divided by the effective area.

\section{Results and discussion}

The results of the experiments for each bed are shown in Table 1.

Temperature, $\mathrm{pH}$ and dissolved oxygen

The temperature profiles show a slight increase along the beds for all the experiments, but no significant $(P>0.05)$ differences were noticed for the planted and unplanted beds. The temperature increase along the bed was probably caused by the increase of microbial activity related to biodegradation processes. Therefore, the effect of the temperature on the removal of COD or $\mathrm{N}$ was neglected.

The average influent $\mathrm{pH}$ was $\sim 7.2$, increasing approximately by one unit in the effluent in all the experiments. Considering that the acetate oxidation produces alkalinity and that the ammonia oxidation through nitrification consumes alkalinity, the alkalinity production due to acetate oxidation was greater than its consumption by nitrification. There was no detection of nitrate or nitrite at the sampling points, even if the oxidation of ammonia occurred in both beds for the different loads. Therefore, simultaneous reduction of nitrate and nitrite through denitrification has 
Fig. 1 Laboratory set-up

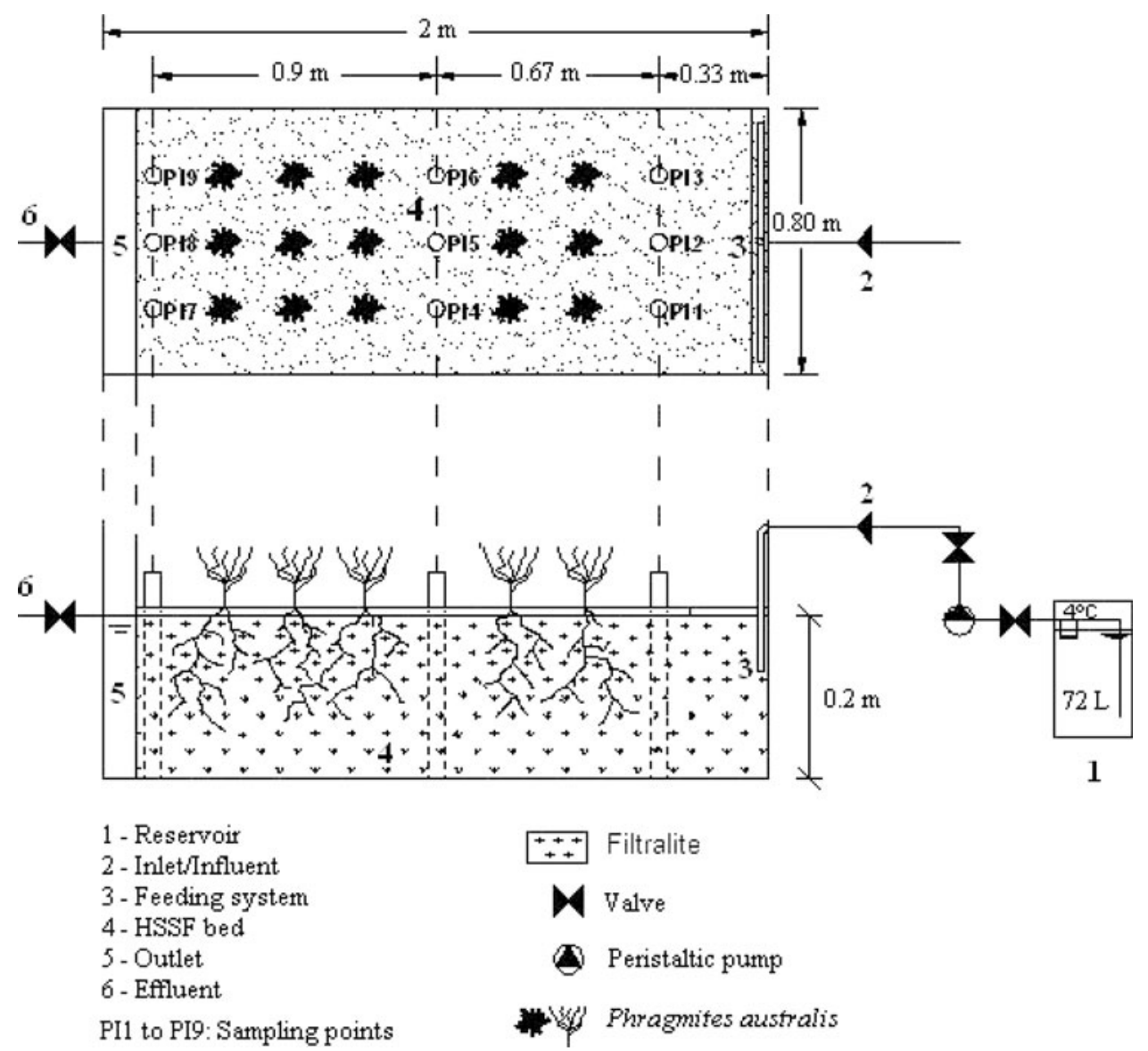

occurred in all the sections and could have also contributed to the $\mathrm{pH}$ increase, since this process produces alkalinity as also observed in Bialowiec et al. (2011, 2012a).

The average effluent $\mathrm{pH}$ decreased with the increase of the NLR, which may be explained by the increase on nitrification as also observed in a previous study with the same laboratory mesocosm (Albuquerque et al. 2009b). The values observed in this study are, however, within the recommended range of values $(4.0<\mathrm{pH}<9.5)$ that allow a good activity of heterotrophic bacteria, denitrifiers and autotrophic nitrifiers (Kadlec and Wallace 2008).

The average DO also decreased along the beds in all the experiments, with a drop to $\sim 0.5 \mathrm{mg} \mathrm{L}^{-1}$ in the first measuring point (PI2), remaining close to zero in the other measuring points (PI5 and PI8) in both the beds. This fast drop of DO immediately after the feeding point is explained by the aerobic removal of COD and $\mathrm{NH}_{4}-\mathrm{N}$ (nitrification) in the first section of the beds (inlet-PI2) due to high oxygen demand.

\section{Effect of loadings and plants on COD removal}

COD concentrations decreased along both planted and unplanted beds, with a bigger drop in the first section
(inlet-PI2), and then continued to decrease slowly until the last sampling point (PI8). The planted bed showed higher removal than the unplanted bed, which was statistically very significant $(P<0.05)$. For the lower OLR (Phase I) the maximum COD removal efficiency (RE) was $87.6 \%$, whilst for the higher OLR (Phase II) the maximum value was $96.2 \%$, in both cases for the planted bed.

For the lower OLR, after 3 weeks of operation period the steady-state conditions were observed at the unplanted bed with an average RE of $39.5 \%$ for COD (the average RE for all the experiments was $38.5 \%$ ). On the contrary, COD removal in the planted bed showed more variability, with average RE of $72.6 \%$ in the first 2 weeks, $57 \%$ after 4 weeks and $73.9 \%$ for the overall experiments. For the higher OLR, a similar trend was observed for both beds with the effluent COD concentrations stabilizing after 2 weeks for the unplanted bed (the average RE for all the experiments was $44.4 \%$ ) and increasing over in time for the planted bed (the average RE for all the experiments was $75.4 \%$ ). The fluctuation in COD removal in the planted bed would mean that the development of plants and roots over time affected the bed dynamics, which influenced organic matter removal.

The lower RE observed in the unplanted bed was probably due to the lower availability of oxygen, which is 


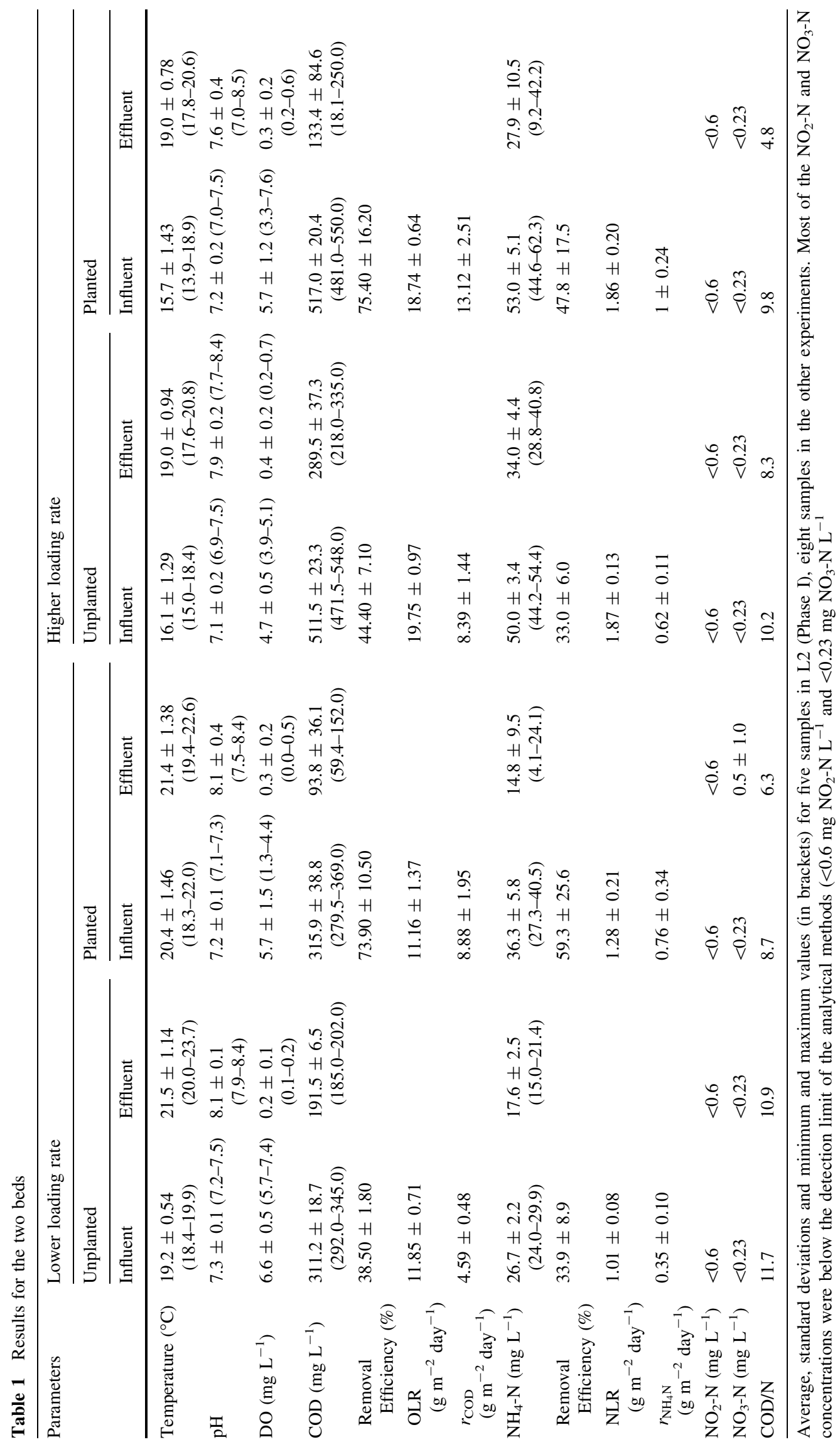


necessary for the microbial degradation of organics. The difference in COD removal observed in both beds is consistent with some works developed in HSFW, which have pointed out that plants may play an important role in the removal of organics (e.g. Tanner 2001; Kadlec and Wallace 2008; Albuquerque et al. 2009b), but inconsistent with others where it was detected the interference of organic exudates (released by roots) on COD removal (e.g. Hunter et al. 2001; Bialowiec et al. 2012a). The results for the planted bed (L2) are within the range of the values found for COD removal (70-90 \%) in LECA-based HSFW working under similar operating conditions (van Deun and van Dyck 2008; Albuquerque et al. 2009b; Bialowiec et al. 2012b).

At the lower OLR the average mass removal rate for COD $\left(r_{\mathrm{COD}}\right)$ was lower in the unplanted bed ( $4.6 \mathrm{~g} \mathrm{~m}^{-2}$ day $^{-1}$ ), increasing to $8.9 \mathrm{~g} \mathrm{~m}^{-2}$ day $^{-1}$ in the planted bed (93.4\% more) as shown in Fig. 2a). At the higher OLR, the average $r_{\mathrm{COD}}$ ranged from $8.4 \mathrm{~g} \mathrm{~m}^{-2}$ day $^{-1}$ (unplanted bed) to $13.1 \mathrm{~g} \mathrm{~m}^{-2} \mathrm{day}^{-1}$ (planted bed), i.e. $56 \%$ more (Fig. 2b). Removal rates normally increased as the OLR increased with a maximum value of $16.3 \mathrm{~g} \mathrm{COD} \mathrm{m}^{-2}$ day $^{-1}$ for the maximum OLR $\left(19.8 \mathrm{~g} \mathrm{COD} \mathrm{m}^{-2} \mathrm{day}^{-1}\right)$. Vymazal and Kropfelova (2008) reports average $r_{\mathrm{COD}}$ in gravel-based HSFW of $8.5 \mathrm{~g} \mathrm{COD} \mathrm{m}^{-2}$ day $^{-1}$, which equals the average value observed in this study for the planted bed at low OLR and for the unplanted bed at the higher OLR. Therefore, regardless both the presence of vegetation and the OLR, Filtralite aggregates seem to improve the removal of organic matter in comparison with gravel aggregates.

Regardless of the OLR, for the unplanted bed, more than $75 \%$ of the COD was removed in the first section (influent-PI2), whilst for the planted bed the removal of COD was better distributed along its length $(42.5-50.3 \%$ in section influent-PI2, $22 \%-30.4 \%$ in section PI2-PI5 and $19.3-35.5 \%$ in section PI5-PI8). In the first section, COD removal seems to have been associated mainly with the aerobic oxidation of acetate carried out by a heterotrophic biofilm since DO concentrations were higher and organic carbon was mainly soluble (acetate). In the remaining sections (PI2-PI5 and PI5-PI8), since the bed was oxygenlimited, COD removal was associated with the oxidation of acetate and other organic material released by roots (exudates) through anaerobic pathways (fermentation and denitrification), and also due to aerobic oxidation in the rhizosphere where oxygen was released by roots. $r_{\mathrm{COD}}$ showed a positive linear correlation with the lower OLR for the unplanted $\left(R^{2}=0.93\right)$ and planted $\left(R^{2}=0.93\right)$ beds (Fig. 3 ) with statistical significance $(P<0.05)$, but no significant linear correlation was found for the higher OLR $\left(R^{2}<0.19\right.$ in both beds) and, therefore, these data are not
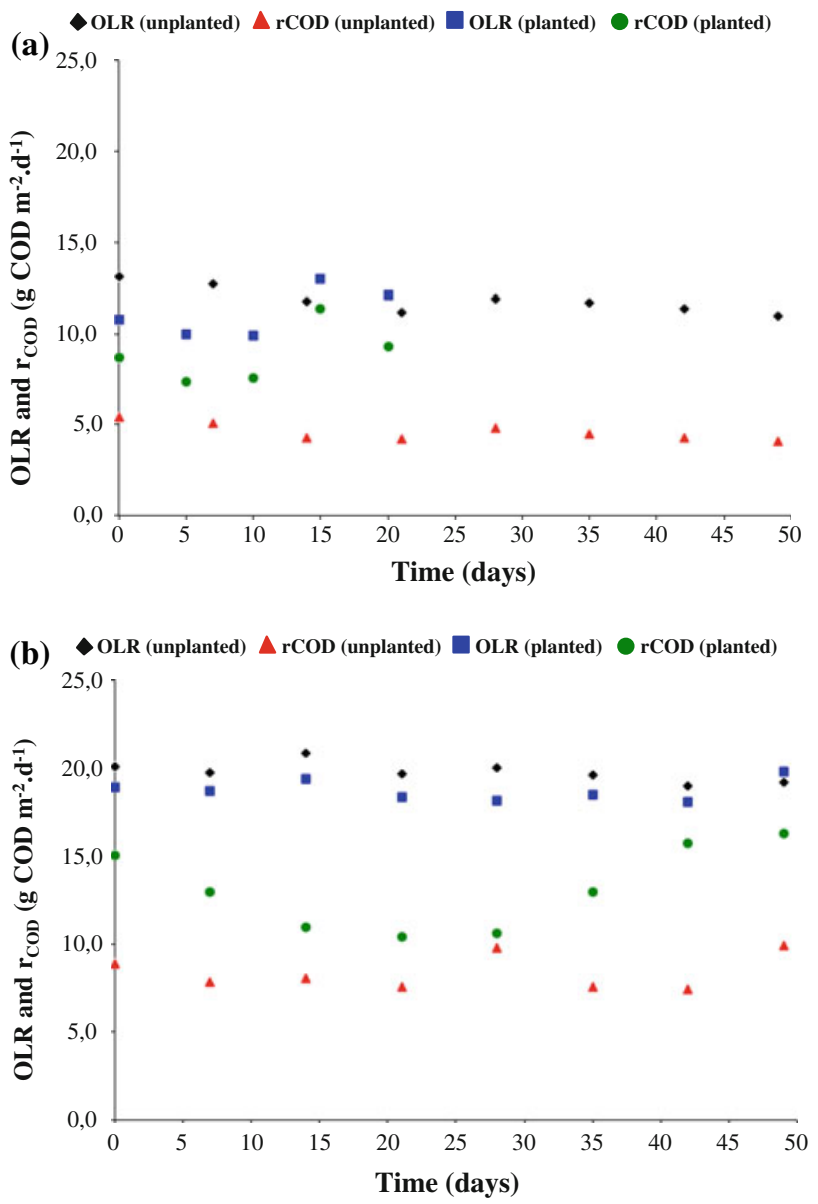

Fig. 2 COD removal rates over time for the lower OLR (a) and higher OLR (b) in the planted and unplanted beds

shown as a figure. Therefore, regardless of the presence of plants, COD loads influence the respective removal rates, for OLR from 10 to $13 \mathrm{~g} \mathrm{COD} \mathrm{m}^{-2} \mathrm{day}^{-1}$.

It seems that planted HSFW improved COD removal due to the combination of mechanisms favoured by plant growth. The growth of rhizomes and roots provides a large surface area and medium for microbial attachment and growth, thus increasing the removal of COD through microbiological pathways. It is also recognized that plants have been linked to the strong redox gradients by releasing oxygen from their roots into the rhizosphere and thereby stimulating aerobic decomposition and growth of nitrifying bacteria (Randerson et al. 2010; Bialowiec et al. 2011, 2012a).

Therefore, high OLR seem to favour the activity of heterotrophic microorganism and consequently increase COD removal, because at high OLR more organic substrates were supplied, which resulted in high heterotrophic production rates as also observed in the work of Wendong et al. (2007). 


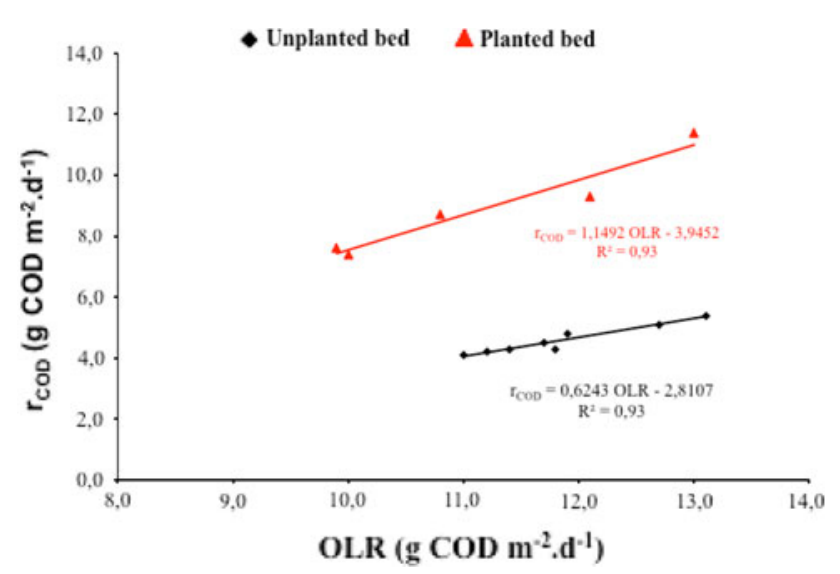

Fig. 3 Relationship between OLR and $r_{\mathrm{COD}}$ in unplanted and planted beds for the lower load (Phase I)

Effect of loadings and plants on $\mathrm{NH}_{4}-\mathrm{N}$ removal

The planted bed presented low effluent $\mathrm{NH}_{4}-\mathrm{N}$ concentrations, suggesting that plants significantly increased the removal of ammonia. When the NLR was doubled (Phase II), the $\mathrm{NH}_{4}-\mathrm{N}$ concentrations in the effluent also increased in both beds. Nitrite and nitrate were not detected in both phases (see Table 1). This circumstance suggests that all nitrate and nitrite formed through nitrification were removed either by denitrification in anoxic zones or were taken up by plants, as were also observed by Albuquerque et al. (2009b) and Bialowiec et al. (2012b).

For the lower NLR, $\mathrm{NH}_{4}-\mathrm{N}$ concentrations slightly decreased along the unplanted bed with overall RE of $23.8 \%$ after 2 weeks, $37.5 \%$ after 4 weeks and $38.2 \%$ after 8 weeks. On the contrary, $\mathrm{NH}_{4}-\mathrm{N}$ removal in the planted bed showed a high variability with a RE of $79.4 \%$ in the first 2 weeks, $43 \%$ after 4 weeks and an average of $59.3 \%$ for the overall experiments. This fluctuation in ammonia removal could be explained by the variation of DO in the rhizosphere, but also due to organic exudates by roots, which normally include organic nitrogen (Pinton et al. 2007; Bialowiec et al. 2012a). Organic nitrogen may be hydrolysed to ammonia, thus increasing the concentrations of this inorganic nitrogen form in the rhizosphere. Therefore, the oxidation of ammonia occurred faster when the ionized form was available and increased again after a few days due to the hydrolysis of organic nitrogen compounds, presumably released by the plants as observed in the studies of Bialowiec et al. (2012a, b). Similar results were observed for the higher NLR. $\mathrm{NH}_{4}-\mathrm{N}$ loss by volatilization was negligible, since only occurred at $\mathrm{pH}$ above 9 (Kadlec and Wallace 2008).

For the unplanted bed the average RE was 33.9 and $33 \%$ for the lower and the higher NLR, respectively, whilst for the planted bed the average RE was higher (59.3 and $47.8 \%$, respectively). These last values are higher than those found in planted mesocosms operating under similar conditions, which reported RE between 30 and $54 \%$ (Hunter et al. 2001; Sun and Austin 2007; Cheng et al. 2011). However, Mander et al. (2000) found high variations in ammonia RE (12-85\%) for planted HSFW, suggesting that there is a higher density and activity of nitrifying biomass in the planted systems as also observed by Stecher and Weaver (2003).

The planted bed showed significantly higher ammonia mass removal $\left(r_{\mathrm{NH}_{4}}\right)$ than the unplanted bed as shown in Fig. 4. The average of $r_{\mathrm{NH}_{4}}$ in the unplanted bed was $0.35 \mathrm{~g}$ $\mathrm{NH}_{4}-\mathrm{N} \mathrm{m}^{-2}$ day $^{-1}$, increasing to $0.76 \mathrm{~g} \mathrm{NH}_{4}-\mathrm{N} \mathrm{m}^{-2}$ $\mathrm{day}^{-1}$ in the planted bed for the lower NLR. For the higher NLR the increase was from $0.62 \mathrm{~g} \mathrm{NH}_{4}-\mathrm{N} \mathrm{m}^{-2}$ day $^{-1}$ to $1 \mathrm{~g} \mathrm{~N} \mathrm{~m}^{-2}$ day $^{-1}$. The removal rates observed in the planted bed are lower than the ones found by Vilpas et al. (2005) in pilot beds treating domestic wastewater, between

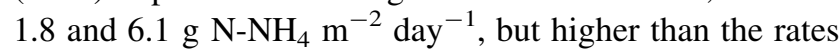
observed by Kuschk et al. (2003) and Scholz (2006) in wetland mesocosms $\left(0.26-0.6 \mathrm{~g} \mathrm{~N}^{-\mathrm{NH}_{4}} \mathrm{~m}^{-2} \mathrm{day}^{-1}\right.$ and

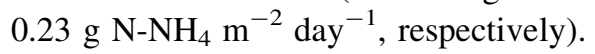

Plants also have an important role in releasing oxygen into the rhizosphere, therefore promoting the development of nitrifiers and aiding in nitrification. Some studies indicate that an aerobic microzone could be present very close to the root surfaces (Armstrong and Armstrong 2005; Bialowiec et al. 2011), enhancing aerobic microbial mechanisms that contribute to organic and ammonia oxidation, which may be a significant contribution to the overall removal of those compounds. Although it was already proved that reeds oxygenate microsites close to the roots (Armstrong and Armstrong 2005), making the DO available for rapid microbial uptake in these areas, there is still insufficient surplus oxygen to oxygenate the remainder of the bed. In fact, the average DO concentration within the two beds and at the outlet was always lower than $0.5 \mathrm{mg} \mathrm{L}^{-1}$, indicating the prevalence of anaerobic/anoxic conditions, which are characteristics of these beds.

When compared to organic matter, ammonia is more difficult to remove as nitrifiers are autotrophic microorganisms that have a slow respiration rate and stoichiometrically require $4.57 \mathrm{mg}$ per $\mathrm{mg} \mathrm{NH}_{4}-\mathrm{N}$ removed (full nitrification) and $1.71 \mathrm{mg}$ per $\mathrm{mg} \mathrm{NH}-\mathrm{N}$ removed (partial nitrification) (Paredes et al. 2007; Kadlec and Wallace 2008). However, Sun et al. (2003) reported that the reduction of ammonia in a down flow reed bed was not balanced by increases in nitrite and nitrate contents in the influent.

When observing the DO measured at the inlet point and the ammonia removed throughout the bed in all experiments it seems that there was not enough oxygen to justify the removal either by full nitrification (oxidation to nitrate) or partial nitrification (oxidation to nitrite). An oxygen balance based on the stoichiometric factors referred above shows 

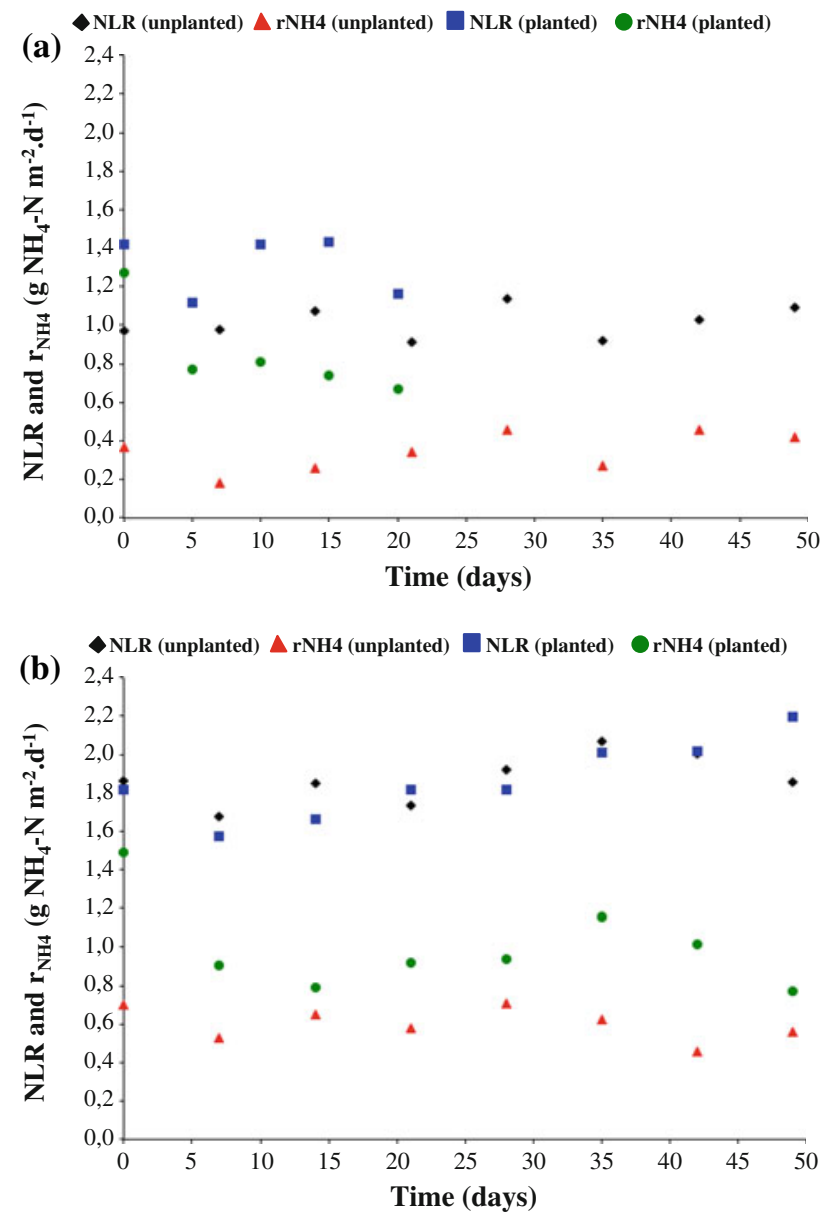

Fig. $4 \mathrm{NH}_{4}-\mathrm{N}$ removal rates over time for the lower NLR (a) and higher NLR (b) in the planted and unplanted beds

that the ammonia removed in both phases in both beds cannot be solely explained by nitrification since it results in a deficit of oxygen. The values are so high that they cannot be explained by additional atmospheric oxygen diffusion into the bed. It seems, therefore, unlikely that there was sufficient oxygen flux to drive the apparent ammonia removal rates observed in the bed through conventional nitrification. In other words, it can be assumed that other non-conventional ammonia removal pathways may have been present. The adsorption of ammonia, nitrite and nitrate in the LECA could also be neglected as proved before through batch adsorption tests (Albuquerque et al. 2009b).

Nitrogen removal in CW has mostly been assumed to be a result of the combination of nitrification-denitrification, plant uptake, assimilation by biomass, precipitation and sedimentation (Vymazal 2007; Kadlec and Wallace 2008). However, newly discovered pathways such as anaerobic ammonia oxidation and heterotrophic nitrification (Paredes et al. 2007) could have potential significance in its loss as observed in the works of Sun and Austin (2007), Tao and Wang (2009) and Albuquerque et al. (2009b). Therefore,

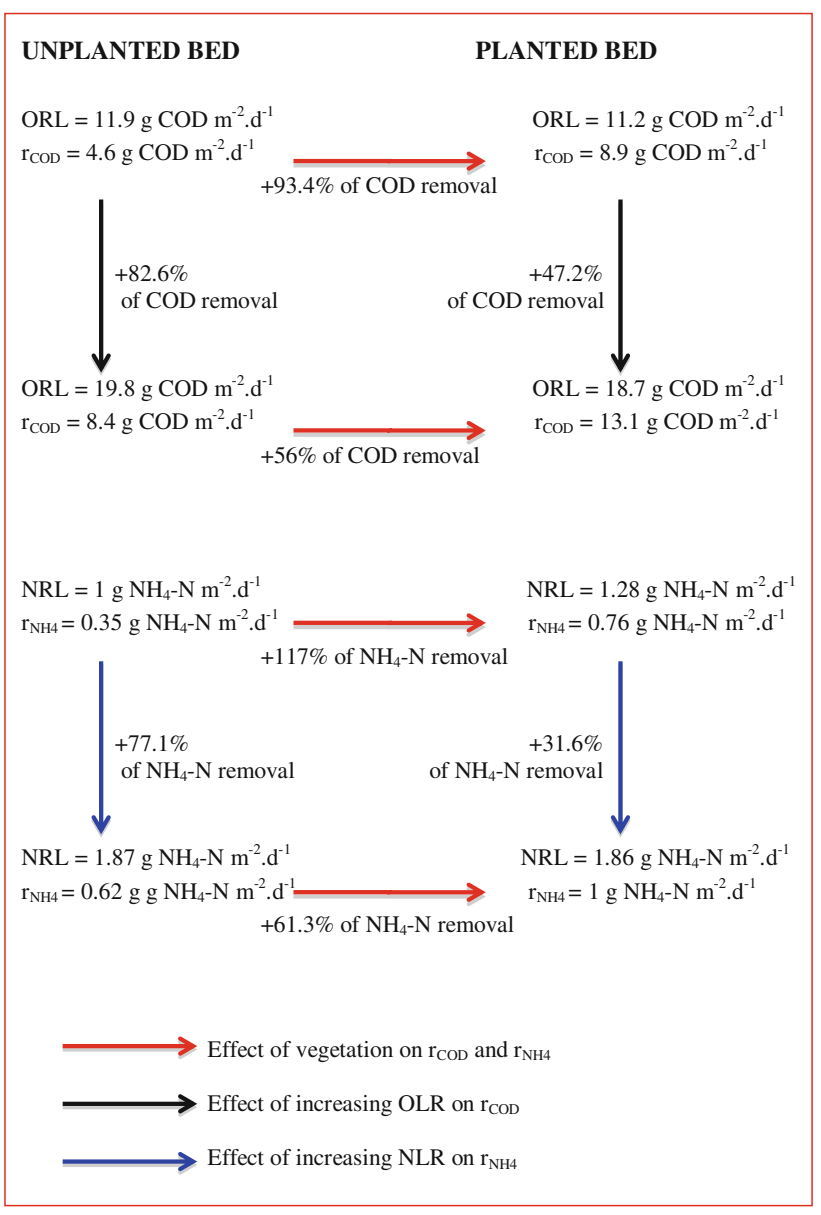

Fig. 5 Effect of plants and loads on the removal of COD and $\mathrm{NH}_{4}-\mathrm{N}$

the loss of ammonia might be a result of a combination of different processes, including conventional and non-conventional pathways of the nitrogen cycle as also observed in other anaerobic biofilm reactors (Paredes et al. 2007; Albuquerque et al. 2009c).

Regardless of the presence of plants and the variation in NLR, a significant linear correlation between NLR and $r_{\mathrm{NH}_{4}}$ $\left(R^{2}<0.25\right.$ and $\left.P>0.05\right)$ was not observed. Therefore, it seems that the NLR was not influenced by the respective removal rates for loads between 1 and $2 \mathrm{~g} \mathrm{NH}_{4}-\mathrm{N} \mathrm{m}^{-2}$ day ${ }^{-1}$.

Therefore, the presence of plants and the increase in both OLR (from $\sim 10$ to $\sim 21 \mathrm{~g} \mathrm{COD} \mathrm{m}^{-2} \mathrm{day}^{-1}$ ) and NLR (from 1 to $2 \mathrm{~g} \mathrm{NH}_{4}-\mathrm{N} \mathrm{m}^{-2}$ day $^{-1}$ ) had a significant impact on the removal of $\mathrm{COD}$ and $\mathrm{NH}_{4}-\mathrm{N}$ as shown in Fig. 5. Phragmites australis requires nutrients for growth and reproduction and ammonia uptake can range between 0.03 and $0.16 \mathrm{~g} \mathrm{~m}^{-2} \mathrm{day}^{-1}$ (Vymazal and Kropfelova 2008), which means a $10-15 \%$ contribution to ammonia removal (Vymazal 2007; Kadlec and Wallace 2008). On the other hand, as roots and rhizomes get more developed, the surface area occupied by nitrifying biofilm also increases. 


\section{Conclusion}

Data from planted and unplanted HSFW suggest that regardless of the applied loads the presence of plants provides a higher removal of $\mathrm{COD}$ and $\mathrm{NH}_{4}-\mathrm{N}$. COD removal was influenced by OLR between 10 and $13 \mathrm{~m}^{-2} \mathrm{day}^{-1}$, but no linear relationship was found for higher OLR, ors for nitrogen. LECA is a very suitable material for CW technology since its both higher porosity and specific surface area allow the fast growth of plants, as well as rapid adhesion and development of biofilm.

Acknowledgments The authors wish to thank the Portuguese Foundation for Science and Technology, which funded the work through the project PTDC/AMB/73081/2006.

\section{References}

Akratos C, Tsihrintzis V (2007) Effect of temperature, HRT, vegetation and porous media on removal efficiency of pilotscale horizontal subsurface flow constructed wetlands. Ecol Eng 29(2):173-191. doi:10.1016/j.ecoleng.2006.06.013. http://www. sciencedirect.com/science/article/pii/S0925857406001285

Albuquerque A, Arendacz M, Gajewska M, Obarska-Pempkowiak H, Randerson P, Kowalik P (2009a) Removal of organic matter and nitrogen in an horizontal subsurface flow (HSSF) constructed wetland under transient loads. Water Sci Technol 60(7):16771682. doi:10.2166/wst.2009.548

Albuquerque A, Oliveira J, Semitela S, Amaral L (2009b) Influence of bed media characteristics on ammonia and nitrate removal in shallow horizontal subsurface flow constructed wetlands. Bioresour Technol 100(24):6269-6277. doi:10.1016/j.biortech.2009.07.016

Albuquerque A, Makinia J, Pagilla K (2009c) Investigations of nitrogen removal pathways in a biological packed bed reactor using elementary mass balances. In: Proceedings of the WEF nutrient removal conference 2009, 28 June to 1 July 2009, Washington, USA, pp 117-135. http://ubi.academia.edu/Antonio Albuquerque/Papers/1022018/Investigations_of_Nitrogen_ Removal_Pathways_in_a_Biological_Packed_Bed_Reactor_ Using_Elementary_Mass_Balances

Amado L, Albuquerque A, Espirito-Santo A (2012) Influence of stormwater infiltration on the treatment capacity of a LECAbased horizontal subsurface flow constructed wetland. Ecol Eng 39:16-23. doi:10.1016/j.ecoleng.2011.11.009

APHA-AWWA-WEF (1999) Standard methods for the examination of water and wastewater, 20th edn. American Public Health Association, Washington, DC. http://pt.scribd.com/doc/44520215/ Standard-Methods-for-the-Examination-of-Water-and-WasteWater-20th-1999

Armstrong W, Armstrong, J (2005) Stem photosynthesis not pressurized ventilation is responsible for light-enhanced oxygen supply to submerged roots of alder (Alnus glutinosa). Ann Bot 96:591-612. doi:10.1093/aob/mci213

Bialowiec A, Janczukowicz W, Randerson P (2011) Nitrogen removal from wastewater in vertical flow constructed wetlands containing LWA/gravel layers and reed vegetation. Ecol Eng 37(6):897-902. doi:10.1016/j.ecoleng.2011.01.013

Bialowiec A, Davies L, Albuquerque A, Randerson P (2012a) Nitrogen removal from landfill leachate in constructed wetlands with reed and willow: redox potential in the root zone. J Environ Manag 97:22-27. doi:10.1016/j.jenvman.2011.11.014
Bialowiec A, Davies L, Albuquerque A, Randerson P (2012b) The influence of plants on nitrogen removal from landfill leachate in discontinuous batch shallow constructed wetland with recirculating subsurface horizontal flow. Ecol Eng 40:44-52. doi: 10.1016/j.ecoleng.2011.12.011

Brisson J, Chazarenc F (2009) Maximizing pollutant removal in constructed wetlands: Should we pay more attention to macrophyte species selection? Sci Total Environ 407(13):3923-3930. doi:10.1016/j.scitotenv.2008.05.047

Cheng B, Hu C, Zhao Y (2011) Effects of plants development and pollutant loading on performance of vertical subsurface flow constructed wetlands. Int J Environ Sci Technol 8(1):177-186. http://www.ijest.org/?_action=articleInfo\&article $=471$

Hunter R, Combs D, George D (2001) Nitrogen, phosphorous and organic carbon removal in simulated wetland treatment systems. Arch Environ Contam Toxicol 41(3):274-281. doi:10.1007/ s002440010249

Jing S, Lin Y, Wang T, Lee D (2002) Microcosm wetlands for wastewater treatment with different hydraulic loading rates and macrophytes. J Environ Qual 31(2):690-696. doi:10.2134/jeq 2002.6900

Juang D, Chen P (2007) Treatment of polluted river water by a new constructed wetland. Int J Environ Sci Technol 4(4):481-488. http://www.ceers.org/ijest/issues/full/v4/n4/404010.pdf

Kadlec R, Wallace S (2008) Treatment wetlands, 2nd edn. CRC Press, Boca Raton

Kuschk P, Wiebner A, Kappelmeyer U, Weibbrodt E, Kastner M, Stottmeister U (2003) Annual cycle of nitrogen removal by a pilot-scale subsurface horizontal flow in a constructed wetland under moderate climate. Water Res 37(17):4236-4242. doi: 10.1016/S0043-1354(03)00163-5

Lu X, Huang M (2010) Nitrogen and phosphorus removal and physiological response in aquatic plants under aeration conditions. Int J Environ Sci Technol 7(4):665-674. http://www. ijest.org/jufile?c2hvd1BERj00Mzg=\&ob=10f50095959a5d8c887 beb3173fa77d3\&fileName=full_text.pdf

Mander U, Kuusemets V, Oovel M, Ihme R, Sevola P, Pieterse A (2000) Experimentally constructed wetlands for wastewater treatment in Estonia. J Environ Sci Health Part A 35(2):13891401. doi:10.1080/10934520009377042

Marecos do Monte H, Albuquerque A (2010) Analysis of constructed wetland performance for irrigation reuse. Water Sci Technol 61(7):1699-1705. doi:10.2166/wst.2010.063

Masi F, Martinuzzib N (2007) Constructed wetlands for the Mediterranean countries: hybrid systems for water reuse and sustainable sanitation. Desalination 215:44-55. doi:10.1016/j.desal. 2006.11.014

Paredes D, Kuschk P, Mbwette T, Stange F, Müller R, Köser H (2007) New aspects of microbial nitrogen transformations in the context of wastewater treatment-a review. Eng Life Sci 7(1):13-25. doi:10.1002/elsc. 200620170

Pedrero F, Albuquerque A, Amado L, Marecos do Monte H, Alarcón J (2011a) Analysis of the reclamation treatment capability of a constructed wetland for reuse. Water Pract Technol 6(3):7. doi: 10.2166/wpt.2011.050 (http://www.iwaponline.com/wpt/006/ wpt0060050.htm)

Pedrero F, Albuquerque A, Marecos do Monte H, Cavaleiro V, Alarcón J (2011b) Application of GIS-based multi-criteria analysis for site selection of aquifer recharge with reclaimed water. Resour Conserv Recycl 56(1):105-116. doi:10.1016/ j.resconrec.2011.08.003

Pinton R, Varanini Z, Nannipieri P (2007) The rhizosphere: biochemistry and organic substances at the soil-plant interface, 2nd edn, CRC Press, Boca Raton

Randerson P, Davies L, Albuquerque A, Bialowiec A (2010) Willows and reeds for bioremediation of landfill leachate: 
redox potential in the root zone. In: Proceedings of the international conference on ECO-TECH'10, 22-24 November 2010, Kalmar, Sweden

Scholz M (2006) Comparison of novel membrane bioreactors and constructed wetlands for treatment of pre-processed animal rendering plant wastewater in Scotland. E-Water 2006/3. http:// www.ewaonline.de/journal/2006_031.pdf)

Stecher M, Weaver R (2003) Effects of umbrella palms and wastewater depth on wastewater treatment in a subsurface flow constructed wetland. Environ Technol 24(4):471-478. doi: $10.1080 / 09593330309385582$

Stottmeister U, Wießner A, Kuschk A (2003) Effects of plants and microorganisms in constructed wetlands for wastewater treatment. Biotechnol Adv 22(1-2):93-117. doi:10.1016/j.biotechadv.2003. 08.010

Sun G, Austin D (2007) Completely autotrophic nitrogen removal over nitrite in lab-scale constructed wetlands: evidence from a mass balance study. Chemosphere 68(6):1120-1128. doi: 10.1016/j.chemosphere.2007.01.060

Sun G, Gray K, Biddlestone A, Allen S, Cooper D (2003) Effect of effluent recirculation on the performance of a reed bed system treating agricultural wastewater. Proc Biochem 39(3):351-357. doi:10.1016/S0032-9592(03)00075-X

Tanner C (2001) Plants as ecosystem engineers in subsurface-flow treatment wetlands. Water Sci Technol 44(11-12):9-17
Tao W, Wang J (2009) Effects of vegetation, limestone and aeration on nitritation, anammox and denitrification in wetland treatment systems. Ecol Eng 35(5):836-842. doi:10.1016/j.ecoleng.2008. 12.003

van Deun R, van Dyck M (2008) Expanded clay and lava rock as potential filter media for nutrient removal in vertical subsurface flow constructed wetlands. In: Proceedings of the society of wetland scientists European ChaTPer meeting, SWS, Kuressaare

Vilpas R, Valve M, Raty S (2005) Report from the pilot plants in Finland. Technical report, Syke, MAXIT-Norden, Finland

Vymazal J (2007) Removal of nutrients in various types of constructed wetlands. Sci Total Environ 380(1-3):48-65. doi: 10.1016/j.scitotenv.2006.09.014

Vymazal J (2009) The use constructed wetlands with horizontal subsurface flow for various types of wastewater. Ecol Eng 35(1):1-17. doi:10.1016/j.ecoleng.2008.08.016

Vymazal J, Kropfelova L (2008) Wastewater treatment in constructed wetlands with horizontal sub-surface flow. Series of Environmental Pollution, vol 14. Springer, Germany

Wendong T, Ken J, William R (2007) Effects of influent strength on microorganisms in surface flow mesocosm wetlands. Water Res 41(19):4557-4565. doi:10.1016/j.watres.2007.06.031 